\title{
Forest Estates/Organisational Units Ranking Model - The MRG Model
}

\author{
Dragan Ratko Čomić ${ }^{*}$
}

(1) University of Banja Luka, Faculty of Forestry, Department of Forest Economics and Organization, Stepe Stepanovica 75a, BA-78000 Banja Luka, Bosnia and Herzegovina

* Correspondence: e-mail: dragan.comic@sf.unibl.org
Citation: ČOMIĆ DR 2019 Forest Estates/ Organisational Units Ranking Model - The MRG Model. South-east Eur for 10 (1): 39-51. DOI: https://doi.org/10.15177/ seefor.19-03

Received: 4 Jun 2018; Revised: 3 Dec 2018; 8 Feb 2019; Accepted: 13 Feb 2019; Published online: 25 Mar 2019

\begin{abstract}
Background and Purpose: The fact that new organizational concepts require comparison and ranking of some business entities, implies the analogy that, in forestry, ranking should create the basis for differentiation of Forest Estates (FE) (seen as profit centers) according to their capability to allocate funds from rent for the utilization of forests and forest land. In this sense, it was necessary to determine the basic criteria and variables, and then to create the model for FE ranking on the basis of ecological and production potentials, and business results (economic indicators). The main idea was to create a model that can be used primarily by forest owners (which are, in certain countries such as Bosnia and Herzegovina, Croatia, Serbia, and Montenegro, mainly governments) and by public forest enterprises. The proposed models may serve to all other scientific, professional, research and other institutions, as the starting point for further research and as suggestions for possible improvements of the proposed solutions.

Materials and Methods: The research was carried out within the project "Differential rent in the Republic of Srpska forestry". Total sample for the survey was 44 interviewed parties, with 118 questionnaires filled in. The methods of classification, content analysis, desk research, analysis, synthesis and comparison were used. In the concrete application of the Forest Estates/Organisational Units Ranking Model (hereinafter MRG Model; Model rangiranja šumskih gazdinstava, in Bosnian), the following methods were used: brainstorming, focus groups, survey, desk research method, Pareto analysis, modelling and induction. The statistical methods used were descriptive statistics and rank correlation. By using these methods and by combining them, a new model for forest estates ranking was created. Different input data and variables that refer to economic and natural indicators were used for ranking, all in accordance with the values for areas for which the ranking was carried out.

Results: The main results are used for defining and proposal of the new model for forests estates ranking, i.e. the MRG Model. This model includes the following steps: (1) Survey, (2) Selection and scoring of specific variables, (3) Determining the intervals for specific variables, (4) Ranking of forest estates, and (5) Validation and rank correlation. This paper presented the algorithm of implementation of specific steps within the MRG Model, together with all activities that need to be implemented in order to perform forest estates ranking. It is necessary to emphasize that forest estates ranking was performed in accordance with the following three ranks: (1) for all analyzed variables, (2) for economic variables, and (3) for natural variables. Additionally, three modules for the calculation of scores for individual forest estates are the result of this research.

Conclusions: The MRG Model is based on FE ranking according to deviation from the average value of the selected variables. The quality of the model lies in the fact that it is relatively simple (there are no complex statistical or other methods, necessary data can be collected easily), and that it can be applied again for similar surveys. Implementation of the MRG Model involves 5 basic steps with 7 phases to be performed in the order specified in this paper. The selection of variables which will be part of the MRG Model is crucial. The survey sample must include representatives that are directly or indirectly involved in the forestry sector. Although it might seem that all selected variables are significant, it is always necessary to give each variable the importance in accordance with the survey results. It is necessary to validate the defined model, data and final ranks on a pilot sample. Since there are three ranks, it is necessary to consider their mutual correlation, by performing statistical analysis rank correlation.
\end{abstract}

Keywords: MRG Model, ranking of forest estates, differential rent in forestry 


\section{INTRODUCTION}

Research results presented in this paper resulted from the project "Differential rent in the Republic of Srpska forestry". The main objective of this project was to, through the analysis of various variables, define the methodology for forest estates ranking (including 26 forest estates) within the Public Forest Enterprise (hereinafter, PFE) Forests $f$ the Republic of Srpska, according to their real capabilities to allocate differential rent funds. In that sense, it was necessary to determine the basic criteria and variables for forest estates ranking, on the basis of natural and production potentials and business results (economic indicators).

The initial idea for this research is related to the allegations stated in paragraph 6 of the Republic of Srpska Government's Proposal [1] of the measures for redefining the organizational, economic and personnel positions within PFE Forests of The Republic of Srpska, where it was pointed out that "the rent as well as the classification of forest estates were not determined, which prevents realistic planning". This was precisely the reason for project activities, and one of its results is the defining of the Forest Estates/Organisational Units Ranking Model (hereinafter MRG Model; Model rangiranja šumskih gazdinstava, in Bosnian) described in this paper. The fact that new organizational concepts require comparison and ranking of some business entities [2], implies the analogy that, in forestry, ranking should create the basis for differentiation of Forest Estates (FE) (seen as profit centers) according to their capability to allocate funds from rent for the utilization of forests and forest land. A review of the previous research [1, 3-19] identified the basic problem, which was the lack of clearly defined methodology which would be, in accordance with certain ecological and business conditions, applied in forestry enterprises in order to rank forest estates, thus creating the basis for their differentiation for allocating funds for forest rent. In this sense, the subject of the research was focused on defining a simpler, scientifically based model, which would be, in more or less altered form, applicable for the periodical ranking of forest estates. The purpose of all the above mentioned requirements is to establish a more operative, more flexible and more profitable system, as well as to create a realistic basis for allocating funds from rent for utilization of forests and forest land. The main idea was to create a model that can be used primarily by forest owners (which are, in certain countries such as Bosnia and Herzegovina, Croatia, Serbia, and Montenegro, mainly governments) and by public forest enterprises [20]. Through research, it was concluded that the issues related to the ranking of enterprises are more present in economic literature sources than in those dealing with the forestry sector. For example, in the publication published by the Institute of Professional Financial Managers [21], there is a statement that the economic potential of an enterprise is used for comparison of the scope of enterprise operations with other enterprises, and for ranking the enterprise at local and international levels. In the same publication, it is also stated that the "comparison of the enterprise ratios with the own indicators only allows identification of the area of development of the enterprise itself and does not provide any information about the ranking of the enterprise within the industry, and does not compare it with its competitor". The logic of these facts was also applied when creating the MRG Model.

Babic and Plazibat [22] pointed out the need for ranking enterprises by using multiple criteria, stating that "since multicriteria analysis provides enterprise ranking in terms of various criteria simultaneously, it is one of the most suitable tools for total approach to the problem of business efficiency analysis". The authors emphasize the need to use the relative efficiency approach, stating that "the value of relative efficiency will provide one with the information about the 'better' enterprise and will have greater importance than just the information about partial efficiency achieved by an observed enterprise".

Even Ivanić [23], as an economist, emphasized the issues of the instruments for renting annuity, stating that "the state must force enterprises to pay rent in order to limit the cuts and make it more expensive, as well as to provide money that would stimulate afforestation and protection of forests". His statement that "some plots in the forestry sector differ, which is a consequence of natural circumstances or social investments" indirectly suggests the need for the ranking of enterprises to which these plots are allocated, in order to create an assumption for more or less allocation of rent annuities, depending on business conditions.

When considering research conducted by forestry economists, research by Šporčić et al. is usually pointed out. Their long-term research [14-18], which was conducted in 2007, 2008, 2009 and 2014, is in its essence very similar to the research conducted for the needs of this paper, and was thus one of the basic prerequisites for the MRG Model development. This research assesses the efficiency of basic organizational units in the Croatian forestry, i.e. forest offices, by applying Data Envelopment Analysis (DEA). The authors state that in forestry, due to numerous forest management objectives, it is very difficult to apply classical economic methods for estimating the efficiency of forest enterprises, which was the reason they had decided to use the DEA. This methodology represents a methodology suitable for the efficiency and productivity analysis of numerous production units, but is not traditionally used in forestry [18]. This method was used for the comparison of organizations [24], regions and countries [25], as well as in various other fields, such as agriculture [26]. One of the foreign authors who used this method for the comparison of enterprises in forestry and paper sectors is Lee [11]. DEA is based on linear programming [27], which may have a potentially complex application, and the selection of variables may be subjective, with subsequent ranking of business units according to individual variables, not according to all business conditions. The MRG Model is aimed at overcoming these issues, with a strict focus on the forestry sector.

Economic performance analysis of forest enterprises, aimed at their ranking according to the achieved profitability indicator, was conducted in 2017 by Hajduchova et al. [6]. The authors stated that performance may serve as a tool for the competitiveness assessment and, in a broader context, for the assessment of its vitality and further development. The research sample consisted of all forest enterprises and thus aggregated data of revenues, costs and profit of all forest enterprises in Slovakia as provided by the Green Reports on Forestry from 2011 to 2015 . Creating an operational tool for 
measuring the performance of forest estates was also one of the basic ideas applied when defining the MRG Model. Further on, the research was based on classical economic indicators which may not be comprehensive since multicriteria approach must certainly be applied, with respect to both economic and natural criteria.

Balážová and Luptáková [3] aimed at pointing to the possibilities of using the Economic Value Added index in evaluating forest enterprises' performance. When calculating the index, they took only the financial statements of a selected forest enterprise for their starting point, and there was no multi-criteria analysis which includes both economic and natural variables.

Certain authors, such as Wolfslehner et al. [19], have used Analytic Hierarchy Process (AHP) method in the forestry sector, which is actually based on ratio scales for the analysis of multiple-criteria decision-making problems [28]. As Wolfslehner stated, Mendoza and Sprouse [29] were the first to apply AHP in forest-management planning, and more recent applications of AHP in multiobjective forest management and land-use planning included Kangas and Kuusipalo [30], Mendoza et al. [31], Vacik and Lexer [32], Vacik et al. [33], Schmoldt et al. [34], and Ananda and Herath [35]. The application of AHP Method can be considered as one of the methods for forest estates ranking, but no papers dealing with that issue have been found.

Pears [36], in addition to other issues, addressed economic issues of tenure systems. He stated that "many forms of using fructuary rights for forests not only provide their holders with rights to use resources, but also assign them management responsibilities". This claim indirectly points to the need for ranking of certain forest users or owners aimed at various obligations in managing this good. The author further states that: "(...) it is important to distinguish the issue of who is responsible for resources management from the question of who will pay for it. This is because licensees who assume such contractual responsibilities are often reimbursed, directly or indirectly, for the cost. The ultimate impact of resource rents thus depends on these financing arrangements as well as more direct fiscal measures".

Oesten and Roeder [37] addressed the issues of classification of enterprises according to economically relevant criteria, for the purpose of comparing the enterprises. It is stated that if the business results (balance and/or calculated profit, net turnover, etc.) differ in spite of the same preconditions for success, the reasons must be sought in differences in operational management, i.e. in creating the factors relevant to the success on which enterprise management can have a short-term influence as well. The authors indicated different variables, favoring one type of variables (the economic one). This research had similar logic and approach to the problem. Speidel [38] suggested variables for the classification of enterprises, which he considers relevant for success and on which enterprise management cannot have a short-term influence, such as: legal form, the size of the enterprise, natural location, the distribution of plant types, the structure of age groups (height and structure of the stock). These variables were considered to a greater or lesser extent when selecting the MRG Model.

For a quality analysis of the presented problems, especially in the Western Balkans region, the research of regional forest economists has to be included. The issues of forest rent and creating equal conditions for the operating of organizational units/estates within forest enterprises, have been addressed by several regional authors which are retrospectively listed as follows.

Potočić [12] suggested that it is necessary that all work collectives are in the same position, with equal or approximately equal prospects for success. Therefore, he defines the problem of determining business results arising from the real merits of a work collective, i.e. from the separation of results which are the consequence of more favorable natural conditions.

Kraljić [13] also referred to the variables on which the forest rent depends, stating that the rent should definitely be separated into two parts, the one which depends on natural conditions and which would, if not necessary for the forestry sector, be allocated to a society (municipality, government), and the other one intended for the development of forestry. The same author [7] had previously addressed the issues of determining organizational units as such and of the distribution of income within an enterprise or at the level of certain units, as well as with the technique of separation of the part of funds, depreciation of forests from a specific organizational unit to the benefit of the entire enterprise and vice versa. The paper focuses on the organization of individual organizational units, and the distribution of financial resources between them. As a continuation, the author refers to stimulating the distribution of income (or profit) between specific organizational units within the enterprise, as well as to financial norms of biological reproduction of forests, analyzed in several papers $[9,39$ 43]. Methods and criteria for the distribution of income and profit, i.e. the sources of funding for equal development of all organizational units, are as follows. In its modified form, the assumption that an equal or at least continuous development of forest areas (managed by certain forest estates) cannot be provided, can be considered as one of the basic purposes of using the results obtained through the MRG Model.

In his further studies, Kraljić [10] referred to the issue of forest rent, i.e. the separation of a part of income which depends on extremely favorable conditions for some forest estates, dividing them into natural, market and other conditions. This classification was used as a guideline for the division of variables when defining the MRG Model.

Golubović [5] raised the question of how to bring work units into an equal starting position in a variety of economic conditions. The paper identifies the differences between the conditions of certain organizational units, which are the result of different average fertilities (classes) of habitats and different average distance from the consumers (market). The variables were given and the amounts of differential rent for specific organizational units were determined.

Ranković [13] addressed the economic function of forest rent and the methods of its calculation. The author points out the problem of active and passive areas, i.e. those areas where a higher amount may be allocated for forest rent, but where there is no need for investing in cultivation and protection, and on the other hand, the areas that do not provide such high amounts for the rent, but where there is a great need for silvicutrure and protection activities. The method of 
separation, i.e. the ranking of active and passive areas is not defined, which indicates the need to define the methodology presented in this paper.

Delić [44] and Delić et al. [45], in addition to the issues of differential rent as extraordinary profit which might be generated, put a special emphasis on rent in forestry, where the graphic presentation well represents the role of the rent within the structure of the market price of forestry products.

Sabadi [46] is one of the regional authors who referred to the rent issues within the economic aspect of the rent calculation, with no detailed analysis of the forestry rent issues and forest estates ranking in accordance with the possibilities of allocating funds for rent.

The research results can primarily be used by forest owners (which are, in certain countries, mainly governments) and public forest enterprises. The proposed models may serve to all other scientific, professional, research and other organizations/institutions, as the starting point for further research and as suggestions for possible improvements of the proposed solutions.

\section{MATERIALS AND METHODS}

\section{Study Area}

The survey which defined the MRG Model was carried out within the project "Differential rent in the Republic of Srpska forestry". The project was financed by the Republic of Srpska Government, Agreement no. 113-4/16 as of 04 February 2016. The research was conducted in the period between April and October 2017. The subject of the survey was PFE Forests of The Republic of Srpska, i.e. 26 forest estates operating within the PFE, which utilizes public forests and forest lands in the Republic of Srpska, Bosnia and Herzegovina.

Field research included a 40-day survey, during June and July 2017. The total sample for the survey was 44 parties, with 118 questionnaires filled in. In addition, the official data issued by the Department of Forestry within the Ministry of Agriculture, Forestry and Water Management, as well as the data contained in the Cadastre of forests and forest land in the Republic of Srpska, production and financial statements of PFE Forests of The Republic of Srpska, and current forest management plans were used. The analyzed data refer to the five-year period, from 2012 to 2016.

\section{Research Methods}

Research methods can be classified into those used during the research for drafting this paper and those used as a part of the MRG Model.

The following research methods were used during the research for drafting this paper [47]: classification, the method of content analysis, desk method, method of analysis, method of synthesis and method of comparison.

Classification, which is used when defining the problem and determining the cause and effect of the problem. This method was primarily used for classification of variables, sources of relevant data and forest estates. The definition of theoretical framework was carried out based on the application of the method of content analysis, within which the identification and analysis of regional and foreign bibliography based on the issues of forest rent and forest estates ranking were carried out as well. Desk method was conducted in order to collect the existing data, that refer to a wide range of identified problems related to the differential rent and conditions for the operating of forest estates. Method of analysis was used for a clear disaggregation of the research subject into components, i.e. factors of structure, function, connections and relationships of the model for forest estates ranking according to more favourable or less favourable business conditions. Method of synthesis was used after description and disaggregation, for interpretation of the obtained data. After the classification and finding the influence factors, the data were linked. On the basis of interpretation and linking, the data were combined into meaningful units, which could be further used within the entire research. Method of comparison was used to determine the identity, similarities and differences between values of the selected variables for different time periods.

The following methods were used as part of the MRG Model: brainstorming, focus groups, survey and Pareto analyses. The statistical methods used were descriptive statistics and rank correlation. Brainstorming technique was used to determine variables that should be taken into consideration when creating the Model. Due to biological, technical and economic specificities in the forestry sector, the identification of all (or the largest number of) variables that may have direct or indirect impact on a particular problem was crucial. The project team identified a total of 106 possible variables. Focus groups were used to collect and isolate certain variables defined through brainstorming and to enable effectiveness during the survey. A total of 106 defined variables were collected and isolated for the survey, thus determining a total of 50 variables that had formed the basis for this research. Through the survey, the validity of variables to be included in the final model was provided.

Following the defined principles for the sample selection, the survey was used as a basis for scoring and ranking of the selected variables. For this concrete research, the survey lasted 40 days, during June and July 2017. The total survey sample included 44 interviewed parties, with 118 questionnaires filled in. Desk method was used for the collection of historical and current data for specific variables specified for the analysis within the MRG Model.

According to the Pareto principle [48], it is claimed that roughly $80 \%$ of the effects come from $20 \%$ of the causes, which means that this principle indicates that, in each population, certain phenomena are significantly more important than the others. This method was used after the survey for the selection of corresponding variables to be included in the final model.

Modelling was used to define the final models for forest estates ranking according to business conditions. Models were defined for three groups of variables: all of the selected ones, natural and economic.

Statistical method applied includes simple descriptive statistics. The option of using regression analysis to define certain statistical methods was considered. However, it was concluded that, due to a large number of variables that are the subject of analysis and that do not have to be necessarily the same in every subsequent research, the application of regression and probably any other more complex multivariate statistical analysis (such as factor analysis) is difficult to apply. It was important to establish a scientifically based and 
representative model for forest estates ranking, which would at the same time be practical, applicable, reproducible and simple for use, as well as easily used by different stakeholders from academic community representatives to representatives of forest enterprises. Rank correlation is applied within the MRG Model, which is more thoroughly presented in the chapter referring to research results.

\section{RESULTS}

As the result of the project "Differential rent in the Republic of Srpska forestry, 26 forest estates within PFE Forests of The Republic of Srpska", were ranked in accordance with ecological/natural and production potentials and their business results (economic indicators). As previously stated, the MRG Model was used for the ranking, and its basic characteristics are given below.

Five basic steps of the MRG Model (also known under its full name The ranking of forest estates according to deviation from the avearge value of the selected variables) are classified into seven basic phases, as follows: (1) Selection of variables, (2) Survey designing and determination of the survey sample, (3) Survey with the processing, analysis of the collected data, and evaluation of certain variables, (4) Determination of the intervals for certain variables, (5) Validation of the defined model, (6) Ranking of forest estates, and (7) Rank correlation.

It is necessary to form an expert team that will conduct all the activities. It is suggested that the team consists of a minimum of 6 members, preferably involving the representatives of various stakeholders (scientific-research institutions, higher education institutions, public forest enterprises, relevant ministries, representatives of the local community, and non-governmental sector).

\section{Selection of Variables}

In the initial phase, it is necessary to identify as many variables that may have direct or indirect impact on the forest estates operation as possible. For the successful implementation of the first research phase, the methods of brainstorming and focus groups are combined. Expert team members, primarily in brainstorming sessions, propose as many variables as possible, which would (in their opinion) have an impact on more favourable or less favourable business conditions for certain forest estates. After the compilation of all suggestions, focus group meetings are organized (expert team members and the representatives of other stakeholders - the number of up to 12 participants is recommended), where all submitted proposals are compiled and the most important variables to be included into the survey questionnaire are selected. For easier reference, it is necessary to sort all variables into three categories, as follows:

1. Economic - which basically includes the following fields: economics, politics, organization, utilization, communication, safety at work, etc. Within this research economic variables which were selected are as follows: cost-effectiveness, volume of realized wood assortments (conifers and broadleaves), productivity (natural and value method), openness of forests.
2. Ecological - which basically includes the following fields: dendrology, pedology, climatology, phytocenology, etc. Within this research none of the offered ecological variables were selected within the top ten.

3. Planning - forest management - which basically includes the following fields: increment, forest management, silviculture, seed growing, etc. Within this research economic variables which were selected are as follows: total and average wood stock, total wood stock of conifers and broadleaves, planned annual cut of conifers and broadleaves, total and average volume increment, site class, and the surface and structure of forest areas according to forest categories.

All variables are considered individually and in the final selection of variables there does not have to be an equal number of variables from the listed categories (economic, ecological and forest management). It is necessary to randomly group the variables in the survey questionnaire, without grouping them into the above mentioned groups.

The importance of each variable may be evaluated by grades 0 to 5 ( 0 - with no impact; 1 - very small impact; 2 small impact; 3 - medium impact; 4 - large impact; 5 - very large impact), and there should be a 'with no opinion' option (I do not have an opinion/sufficient information) for those variables for which the participants are not sure or competent for or have no sufficient information. When analyzing the data, the answers 'with no opinion' should not be included in the calculation of the average grade.

\section{Survey Designing and Determination of the Survey Sample}

After preparation of the final version of the survey questionnaire, the sample for the survey is determined. In order to define a quality model, it is necessary to include as many stakeholders as possible (recommended minimum is $\mathbf{5 0}$ respondents/filled questionnaires), primarily in the field of forestry, as well as in the fields that are directly or indirectly related to forestry. The survey refers to individuals, and does not reflect official attitudes of certain organizations or institutions. In this regard, the following criteria for the group of respondents were set:

- The questionnaire has to be filled in only by a person with BSc in Forestry (or those with higher level of education);

- The questionnaire may be filled in by experts in other fields as well (with a high level of education), who are directly or indirectly involved in forestry activities (for example, economic experts who are in charge of commercial activities in forest enterprises);

- In each forest estate and other organizational units (such as Directorate) within Public Forest Enterprise, at least one respondent must fill in the questionnaire, preferably the most experienced one;

- The survey should be conducted in as many higher education and scientific-research institutions, organizations and institutions in the field of forestry or related activities as possible.

The total survey sample was 44 interviewed parties, with 118 questionnaires filled in. 
Survey, Processing, Analysis of the Collected Data, and Evaluation of Certain Variables

After collecting and processing the data obtained from the questionnaires, all variables had to be ranked in accordance with the number of points won, i.e. based on the average importance of a certain variable as evaluated by the participants in the survey. Based on all analyzed questionnaires, the average grade for each variable was determined.

For creating a practical and applicable model, it is not possible to consider all variables included in the questionnaire. Therefore, in accordance with the Pareto principle (80/20) [48], it is necessary to select $20 \%$ of the most important variables, i.e. those which after the conducted survey, data processing and analyzing, have the highest number of points.

The average value was determined (simple arithmetic mean) for all variables included in the model $(20 \%$ of the selected variables from the questionnaire), after which a percentage deviation of the average grade of each variable from the average value of all variables was determined. Deviation (if any) can, naturally, be positive or negative. For this specific research, it is presented in Table 1.

Although in some cases (as noted above) average grades for certain variables do not differ much (3.70\% maximum), it is always necessary to give each variable the importance in accordance with the survey results. This is achieved by defining the adjusted scale of points for each individual variable, as described below.
Scale from 0 to 5 is determined for the initial scoring of all variables, and the number of points for certain variables is determined according to the percentage deviation of the average grade of certain variables from the average grade of all selected variables. This implies that the initial scale from 0 to 5 is multiplied by the percentage deviation of the average value of certain variables from the average grade of all variables (4.21 in this case). For example, in the first variable presented in Table 2, deviation of the average grade of certain variables from the average grade of all variables is $3.70 \%$. This further means that the scale of points for this variable is as shown in Table 2.

The scoring of specific variables is in accordance with Equation 1.

$$
B_{v}=P_{s}+\% \text { of deviation from the average grade }
$$

where $B_{v}$ is points for a single variable, and $P_{s}$ is the initial scale defined (0 to 5).

\section{Determining the Intervals for Certain Variables}

In accordance with the specifics of each research area, it is necessary to determine the interval of the value for each variable, which was evaluated by the defined number of points in the previous step. This implies that for certain points (as in the previous example, 0 to 5.185), it is necessary to determine the interval (i.e. intervals) for the observed variable. An example of variables and average wood stock is given in Table 3.

TABLE 1. Selected variables for creating the model, ranked according to the average grades.

\begin{tabular}{|c|c|c|c|}
\hline No. & Variable & Average grade & $\begin{array}{l}\text { Deviation from the average value of } \\
\text { all selected variables (\%) }\end{array}$ \\
\hline 1. & Total and average wood stock & 4.37 & +3.70 \\
\hline 2. & Total wood stock of conifers and broadleaves & 4.27 & +1.33 \\
\hline 3. & Cost-effectiveness & 4.26 & +1.09 \\
\hline 4. & The volume of realized wood assortments (conifers and broadleaves) & 4.25 & +0.85 \\
\hline 5. & The planned annual cut of conifers and broadleaves & 4.23 & +0.38 \\
\hline 6. & Total and average volume increment & 4.21 & -0.09 \\
\hline 7. & Site class & 4.17 & -1.04 \\
\hline 8. & Openness of forests & 4.15 & -1.52 \\
\hline 9. & Productivity (natural and value method) & 4.13 & -1.99 \\
\hline \multirow[t]{2}{*}{10.} & Surface and structure of forest areas according to forest categories & 4.10 & -2.71 \\
\hline & Average value of all grades & 4.21 & 0.00 \\
\hline
\end{tabular}

TABLE 2. An example of determining the scale of points for a specific variable.

\begin{tabular}{cccc}
\hline $\begin{array}{c}\text { Initial } \\
\text { scale }\end{array}$ & $\begin{array}{c}\text { Percentage difference between the average } \\
\text { grade of the subject variable and the average } \\
\text { grade of all variables }\end{array}$ & $\begin{array}{c}\text { Absolute value of the deviation } \\
\text { from the average grade }\end{array}$ & $\begin{array}{c}\text { Score scale for the subject } \\
\text { variable }\end{array}$ \\
(A) & (B) & (C=A*B) & (D=A+C) \\
\hline 0 & $+3.70 \%$ & 0 & 0 \\
1 & $+3.70 \%$ & 0.037 & 1.037 \\
2 & $+3.70 \%$ & 0.074 & 2.074 \\
3 & $+3.70 \%$ & 0.111 & 3.111 \\
4 & $+3.70 \%$ & 0.148 & 4.148 \\
5 & $+3.70 \%$ & 0.185 & 5.185 \\
\hline
\end{tabular}


The intervals were determined after collecting, processing and analysis of the data on the observed variable, which refer to the current condition of that variable in a certain forest estate. For each variable, maximum and minimum values were determined. Then the difference between the maximum and minimum values was divided by 5 (according to the fact that it is necessary to determine the intervals for 5 scores), and thus the value of one interval was obtained. Furthermore, one value of the interval for each point was added to the minimum value for the observed variable. Value between 0 to the minimum is always scored with 0 points. The specified procedure for determining the intervals for some points is presented in Equation 2 and Table 4.

$$
I_{v}=\frac{V_{\max }-V_{\min }}{5}
$$

where $I_{v}$ is the value of one interval, $V_{\max }$ is the maximum value of the observed variable, $V_{\min }$ is the minimum value of the observed variable.

On the basis of concrete values in the field (for example, real total and average wood stock), each forest estate has a certain number of points per individual variable. Thus, all forest estates that are subject to analysis are scored by each of the selected variables. Based on the sum of the scores per each variable, the ranking list of forest estates in accordance with realistic business conditions is obtained.

\section{Validation of the Defined Model}

It is necessary to validate the defined model on a pilot sample through a direct contact with the representatives of forest estates, by organizing workshops with representatives of small, medium and large forest estates within the PFE. Through a direct presentation of the method of determining and the selection of variables, as well as the defined model, it is necessary to obtain feedback from the representatives of forest estates on possible suggestions for corrections and amendments of the defined model.

\section{The Ranking of Certain Forest Estates}

Certain forest estates are ranked in accordance with the sum of points for all analyzed variables. On the basis of the total number of scores for each forest estate, they were ranked according to more favourable or less favourable conditions and possibilities to achieve (among other things) positive business results.

In that sense, forest estates are primarily ranked in accordance with the total number of scores for all analyzed variables. In addition, in order to separate and analyze "all the rents together" [9], besides the ranking in accordance with the scoring for all variables, it is also necessary to additionally analyze those variables that refer to natural conditions (mostly variables that represent natural conditions for performing business activities), as well as those with an economic component of business operations (caused mainly by anthropogenic, i.e. economic and organizational factors). The first group of variables is determined by general natural (habitual) potential, as well as by the condition of basic factors affecting forest estates ranking, which are quantitatively presented in the forest management plan. The other group of variables is the result of strong human influence on their values, and thus on forest estates ranking. The ranking of forest estates on the basis of these analyses provides the definition of their rank with regard to overall forest management conditions.

TABLE 3. Example of intervals for a variable: total and average wood stock.

Total and average wood stock

\begin{tabular}{ccr}
\hline $\begin{array}{c}\text { Scoring points for a } \\
\text { variable }\end{array}$ & $\begin{array}{c}\text { Scoring points for a variable total wood stock } \\
\left(\mathrm{m}^{3}\right)\end{array}$ & $\begin{array}{c}\text { Scoring points for a variable average wood stock } \\
\left(\mathrm{m}^{3} \cdot \mathrm{ha}^{-1}\right)\end{array}$ \\
\hline 0 & Up to $1,264,000$ & Up to 190 \\
1.037 & $1,264,001-3,506,922$ & $190.10-255.21$ \\
2.074 & $3,506,923-5,749,844$ & $255.22-320.42$ \\
3.111 & $5,749,845-7,992,766$ & $320.43-385.63$ \\
4.148 & $7,992,767-10,235,688$ & $385.64-450.84$ \\
5.185 & $10,235,689-12,479,449$ & $450.85-517.04$ \\
\hline
\end{tabular}

TABLE 4. The specified procedure for determining the intervals for points from 0 to 5.

\begin{tabular}{lr} 
Number of points & Values \\
\hline 0 (previous example 0) & From 0 to $\mathrm{V}_{\text {min }}$ \\
1 (previous example 1.037) & $\mathrm{V}_{\min }+\mathrm{I}_{\mathrm{v}}=\mathrm{I}_{1}$ \\
2 (previous example 2.074) & $\mathrm{I}_{1}+\mathrm{I}_{\mathrm{v}}=\mathrm{I}_{2}$ \\
3 (previous example 3.111) & $\mathrm{I}_{2}+\mathrm{I}_{\mathrm{v}}=\mathrm{I}_{3}$ \\
4 (previous example 4.148) & $\mathrm{I}_{3}+\mathrm{I}_{\mathrm{v}}=\mathrm{I}_{4}$ \\
5 (previous example 5.185) & $\mathrm{I}_{4}+\mathrm{I}_{\mathrm{v}}=\mathrm{I}_{5}$ \\
\hline
\end{tabular}

$\mathrm{I}_{\mathrm{v}}$ - value of one interval; $\mathrm{V}_{\max }$ - maximum value of the observed variable; $\mathrm{V}_{\min }-$ minimum value of the observed variable;

$I_{1,2,3,4,5}$ - intervals for some scores between 1 and 5 
After the ranking, it is necessary to divide all forest estates into 5 groups, according to more favourable or less favourable business conditions. The groups of forest estates are as follows:

- A group of forest estates (the most favourable business conditions),

- B group of forest estates (favourable business conditions),

- C group of forest estates (medium favourable business conditions),

- D group of forest estates (satisfactory business conditions),

- E group of forest estates (the least favourable business conditions).

Each group includes $20 \%$ of forest estates. If it is not possible to divide forest estates into 5 equal groups through calculation, the grouping is done in accordance with a bottomup principle (first, one forest estate is added into the group $E$, and if necessary, another forest estate is added into the group $D$, and so on to the group B).

It must be emphasized that the ranking within certain groups is important, since the higher rank implies a better position within the group. In that sense, after the ranking, all forest estates are labelled as, for example, A-3, B-5, C-1 and so on.

Forest estates are divided into 5 groups, primarily in order to give the decision-makers the opportunity for a possible differentiation of forest estates into more groups according to the possibility of allocating funds for the use of forests and forest land.

Within this research, the following models were defined:

MODULE 1. Calculation of scores for one forest estate by all analyzed variables.

$\mathbf{B}_{\mathrm{g}}=\left(1,037\right.$ to 5,185 for $\left.\mathbf{V}_{\mathrm{u}}\right)+\left(1,037\right.$ to 5,185 for $\left.\mathbf{V}_{\mathrm{p}}\right)+(1,013$ to 5,067 for $\left.\mathbf{V}_{c u}\right)+\left(1,013\right.$ to 5,067 for $\left.V_{c p}\right)+(1,011$ to 5,055 for $E)+(1,009$ to 5,043 for SDS $)+(1,009$ to 5,043 for SDS $)+$ $\left(1,004\right.$ to 5,019 for $\left.\mathbf{E T}_{\mathrm{c}}\right)+\left(1,004\right.$ to 5,019 for $\left.\mathrm{ET}_{1}\right)+(0,999$ to 4,996 for $\left.I_{u}\right)+\left(0,999\right.$ to 4,996 for $\left.I_{p}\right)+\left(0,990\right.$ to 4,948 for $\left.B_{c}\right)$ $+\left(0,990\right.$ to 4,948 for $\left.B_{1}\right)+(0,985$ to 4,924 for $\mathbf{O})+(0,980$ to 4,901 for $\left.\mathbf{P}_{n}\right)+\left(0,980\right.$ to 4,901 for $\left.\mathbf{P}_{v}\right)+\left(0,973\right.$ to 4,865 for $\left.\mathbf{P}_{v s}\right)$

MODULE 2. Calculation of scores for one forest estate by natural variables.

$\mathbf{B}_{g}=\left(1,037\right.$ to 5,185 for $\left.\mathbf{V}_{u}\right)+\left(1,037\right.$ to 5,185 for $\left.\mathbf{V}_{p}\right)$ $+\left(1,013\right.$ to 5,067 for $\left.\mathbf{V}_{\text {cu }}\right)+\left(1,013\right.$ to 5,067 for $\left.\mathbf{V}_{\text {cp }}\right)+$ $\left(1,009\right.$ to 5,043 for $\left.\operatorname{SDS}_{\mathrm{c}}\right)+\left(1,009\right.$ to 5,043 for SDS $\left._{1}\right)+$ $\left(1,004\right.$ to 5,019 for $\left.\mathbf{E T}_{\mathrm{c}}\right)+\left(1,004\right.$ to 5,019 for $\left.\mathbf{E T}_{1}\right)+(0,999$ to 4,996 for $\left.I_{\text {f }}\right)+\left(0,999\right.$ to 4,996 for $\left.I_{\text {f }}\right)+(0,990$ to 4,948 for $\left.\mathbf{B}_{c}\right)+\left(0,990\right.$ to 4,948 for $\left.\mathbf{B}_{1}\right)+\left(0,973\right.$ to 4,865 for $\left.\mathbf{P}_{v s}\right)$

MODULE 3. Calculation of scores for one forest estate by economic variables.

$\mathbf{B}_{\mathrm{g}}=(1,011$ to 5,055 for $\mathbf{E})+(0,985$ to 4,924 for 0$)$

$+\left(0,980\right.$ to 4,901 for $\left.P_{n}\right)+\left(0,980\right.$ to 4,901 for $\left.P_{v}\right)$

where $\mathrm{B}_{\mathrm{g}}$ is total number of scores for one forest management unit, $V_{u}$ is total wood stock, $V_{p}$ is average wood stock, $V_{c u}$ is total stock (conifers), $V_{\text {us }}$ is total stock (broadleaves), $E$ is effectiveness, SDS is forest assortment (conifers), SDS is forest assortment (broadleaves), ET is annual cut (conifers), ET, is annual cut (broadleaf), I is total increase I is average increase, $B_{c}$ is site class (conifers), $B_{\text {, }}$ is site class (broadleaves), $O$ is forest openness, $P_{n}$ is productivity (natural method), $P_{v}$ is productivity (value method), and $P_{v s}$ is area of high forests.

These modules are the result of this concrete survey and serve for the ranking of forest etates operating within PFE Forests of The Republic of Srpska. In such form, the moduls cannot be applied to other areas, and it is necessary to form new moduls according to specific business conditions.

The results of this research, i.e. the ranking and division (into five groups) of all forest estates operating within PFE Forests of The Republic of Srpska, based on natural, economic and unified (natural and economic) variables, is shown in Tables 5 to 7.

\section{Rank Correlation}

As stated in the previous chapter, the MRG Model application defines three ranks of forest estates, as follows:

1. Rank for all variables,

2. Rank for variables for natural conditions,

3. Rank for variables for economic conditions.

Since there are three ranks, it is necessary to consider their mutual correlation. If we want to determine the degree of correlation of the features whose values have been ranked, it is necesssary to perform a statistical analysis that represents a special form of simple correlation, which is called a rank correlation $[3,45]$. Rank correlation is performed for all rank combinations, as follows: (1) Rank of all variables and natural variables, (2) Rank of all variables and economic variables, (3) Rank of natural variables and economic variables.

In order to determine the degree of correlation (compliance) between the specified ranks of forest estates according to the grouped variables, it is necessary to determine Spearman's rank correlation coefficient [49-51] as follows:

$$
r_{s}=1-\frac{6 \sum d_{i}^{2}}{n^{3}-n}
$$

where $r_{s}$ is Spearman's rank correlation coefficient, $d_{i}$ is difference between the ranks, $\mathrm{n}$ is number of forest estates.

In this way, for this specific research, correlation between the specific ranks was determined, i.e. it was determined whether the ranking of all variables complies with the rank for natural variables or the rank for economic variables. In this research, Spearman's rank correlation coefficient for all variables and natural variables was 0.94 , for all variables and economic variables was 0.48 , and for natural variables and economic variables it was only 0.19 . Naturally, for each new research, new variables would probably be used (depending on the results of the survey). Although the rank correlation indicates a lower or higher connection, the rank for all variables is considered to be the final result of forest estates ranking.

\section{Algorithm for the MRG Model}

On the basis of all the above, and for greater transparency, algorithms for the MRG Model are given in Figure 1. 


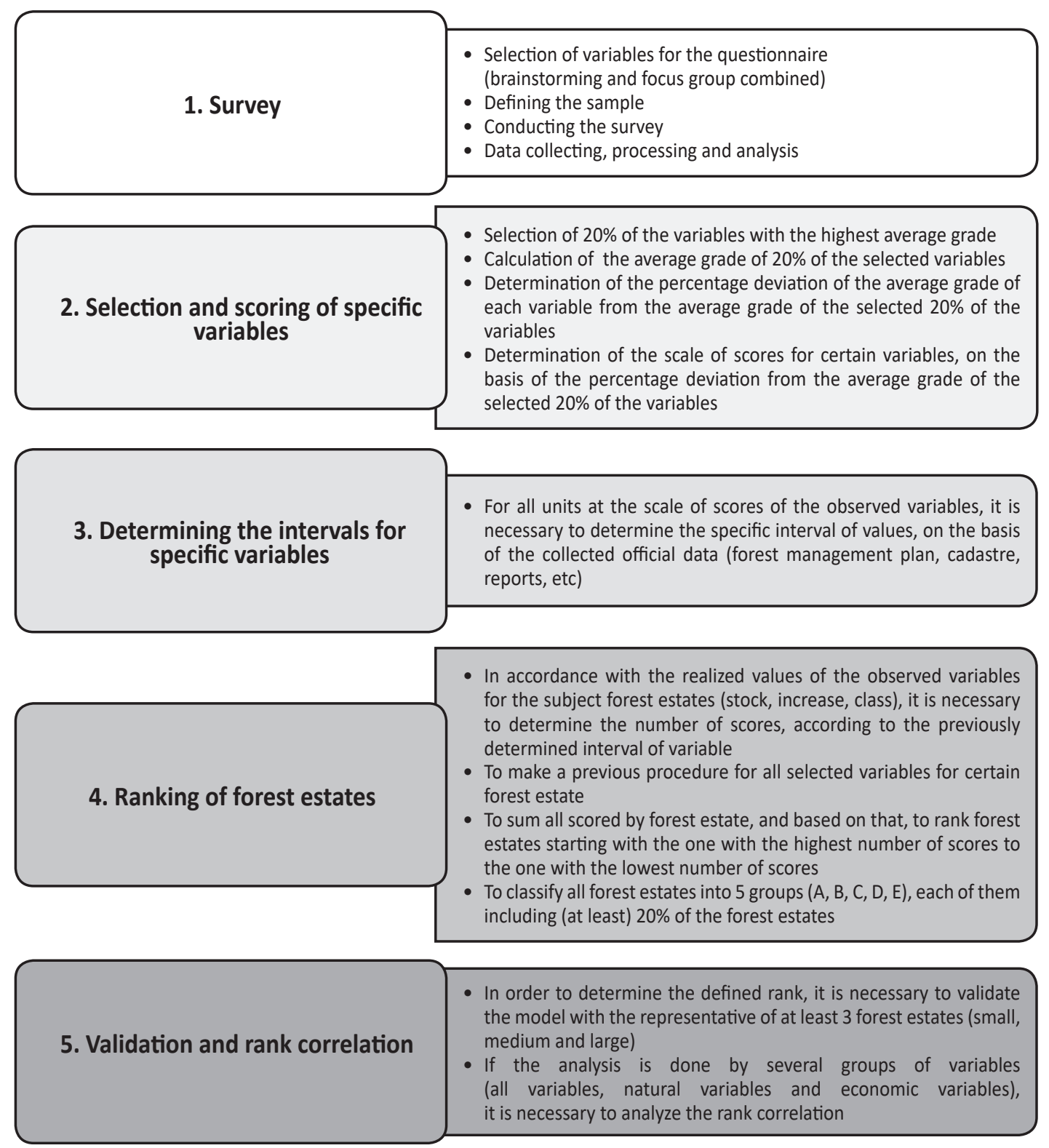

FIGURE 1. The algorithm for forest estates ranking - the MRG Model.

TABLE 5. Division of forest estates operating within PFE Forests of The Republic of Srpska into groups according to all the analyzed variables.

\begin{tabular}{cccccc}
\hline & Group A & Group B & Group C & Group D & Group E \\
\hline 1. & Visocnik & Borja & Vucevica & Banja Luka & Birac \\
2. & Romanija & Ribnik & Drina & Sjemec & Milici \\
3. & Gradiska & Gorica & Vrbanja & Cemernica & Doboj \\
4. & Prijedor & Klekovaca & Jahorina & Panos & Zelengora \\
5. & Maglic & Ostrelj & Lisina & Treskavica & Majevica \\
6. & & & & Botin \\
\hline
\end{tabular}


TABLE 6. Division of forest estates operating within PFE Forests of The Republic of Srpska into groups according to the natural variables.

\begin{tabular}{cccccc}
\hline & Group A & Group B & Group C & Group D & Group E \\
\hline 1. & Romanija & Gorica & Vucevica & Drina & Majevica \\
2. & Visocnik & Prijedor & Klekovaca & Panos & Zelengora \\
3. & Gradiska & Borja & Banja Luka & Cemernica & Botin \\
4. & Ribnik & Jahorina & Vrbanja & Lisina & Treskavica \\
5. & Maglic & Ostrelj & Sjemec & Birac & Milici \\
6. & & & & Doboj \\
\hline
\end{tabular}

TABLE 7. Division of forest estates operating within PFE Forests of The Republic of Srpska into groups according to the economic variables.

\begin{tabular}{cccccc}
\hline & Group A & Group B & Group C & Group D & Group E \\
\hline 1. & Klekovaca & Treskavica & Vucevica & Ribnik & Zelengora \\
2. & Drina & Prijedor & Doboj & Romanija & Botin \\
3. & Vrbanja & Gradiska & Maglic & Cemernica & Jahorina \\
4. & Visocnik & Milici & Ostrelj & Sjemec & Birac \\
5. & Lisina & Borja & Gorica & Banja Luka & Panos \\
6. & & & & Majevica \\
\hline
\end{tabular}

\section{DISCUSSION}

Implementation of the MRG Model involves 5 basic steps with 7 phases to be performed in the order specified in this paper. Discussion on certain steps (phases) refers to the following:

- The selection of variables which will be part of the MRG Model is crucial. It is necessary to apply all the above scientific methodologies and techniques, as well as to conduct the survey on a representative sample, as large as possible. This will ensure the actuality of the selected variables, and give credibility to the defined ranks.

- It is best to classify variables into several groups (in this specific case, into economic, ecological and planning - forest management), without favouring any of the groups of variables. It is necessary to randomly classify the variables in the questionnaire, without grouping them into the defined groups. This will ensure impartiality during the survey, which is one of the basic conditions for defining a quality model.

- The survey sample has to be representative and include individuals who are directly or indirectly involved in the forestry sector. The MRG Model suggests that the questionnaires represent individuals' attitudes, and possible modification may imply that this represents the official attitude of institutions. However, this might lead to possible non-objectivity due to different interests of participants in the survey, and therefore a sample with as many experienced individuals as possible is recommended.

- Due to the convenience of the model, it is necessary to determine the realistic number of variables to be analyzed thoroughly. It is recommended always to use the Pareto principle (80/20), which would certainly involve a different number of variables in accordance with the subject area analyzed.

- Although it might seem that all selected variables are significant, and although in some cases average grades for certain variables do not differ much, it is always necessary to give each variable the importance in accordance with the survey results. This is possible by defining a custom scale for each variable, as explained in this paper. Within the MRG Model, the initial scale ranges from 0 to 5 , and possible modification can be made in terms of creating the initial scale from 0 to 10. Although this would provide even more precise differentiation, there is a possibility of complicating the model which would lead to more difficult work during the data analysis.

- In accordance with the specifics of each research area, it is necessary to determine the interval of value for each variable, which would be evaluated by the defined number of points in the previous step. This operation will vary most in accordance with the area analyzed.

- It is always necessary to validate the defined model, i.e. the data and final ranks, through pilot samples. Within this survey, three pilot samples were used, although a larger number of forest estates could be used as well. This is very important since it contributes to the credibility of the defined model, which might further have a decisive importance in the differentiation of forest estates according to the rate of allocated funds.

- Certain forest estates are ranked in accordance with the total number of scores for all analyzed variables. It is always necessary to define three ranks, as follows: for all analyzed variables, as well as for economic and for natural variables. That procedure will enable additional analysis and identification of the causes of problems for 
specific forest estates. It should be noted that in some cases, one group of variables (economic or natural) might not be selected by the participants in the survey. It is always recommended for both groups to be present in the model (they do not have to be in the same ratio), which is why the determining of the sample is crucial. In that sense, representatives of different stakeholders (including the owners and users of forests, forestry enterprises, higher education institutions, the Chamber of Commerce and non-governmental sector) must be included in the sample.

- The classification of forest estates divided into 5 groups $(A, B, C, D$ and $E)$, as well as the ranking within the groups (A-4, C-1, D-3 etc), is considered quite satisfactory. If necessary, in case of a large number of organization units within a business system (this research included 26 forest estates), the introduction of additional groups may be considered.

- Finally, since there are three ranks, it is necessary to always consider mutual correlation of these ranks, by performing a statistical analysis rank correlation. In this way, mutual correlation of specific ranks is determined, i.e. it is determined whether the ranking for all variables is more compatible with the rank for natural variables or the rank for the economic ones. This provides the possibility for additional business analysis and identification of the causes of problems for specific forest estates.

Application of the MRG Model requires a strict adherence to all parts of the methodology defined within this paper, which implies that all activities must be adapted to the conditions of the area subject to research. Similar methods might be created for future ranking, but all elements of the MRG Model must be implemented from the very beginning.

In this concrete research, a control method was also carried out (based on the Pareto principle), but it was not addressed in this paper. However, the application of a control method is recommended in order to compare the obtained results and to indicate possible deviation of the ranks defined according to different methods. The control method and its testing on pilot forest estates confirmed that the MRG Model is fully applicable and that it enables a realistic forest estates ranking .

\section{CONCLUSIONS}

Finally, here is a list of basic conclusions:

- The MRG Model can be used in all forest enterprises where it is necessary to rank certain organizational units/estates, regardless of the ownership structure;

- Due to the variability of the selected variables and the change of their values in certain time intervals (especially in the case of economic variables), it is recommended to rank forest estates periodically, every five years (or even more often);

- It is recommended to use the control method, since it can indicate certain deviations in forest estates ranking, but it is not mandatory;

- Primary purpose of the ranking using the MRG Model is to indicate the possibility or differentiation of specific forest estates for allocating funds for simple and expanded reproduction of forests. This would (approximately) enable equitable and continuous development of all areas managed by forestry enterprises (or those in their use);

- The allocation rates for forest estates should be a subject of another survey, and should be adapted to areas (states) in which the survey is conducted;

- In order to avoid discontent in forest estates that, due to their higher ranks, should allocate more funds, it is necessary to create special administrative or financial measures of stimulation.

\section{Acknowledgments}

Scientific-research project "Differential rent in the Republic of Srpska forestry" was implemented in cooperation with the RS Ministry of Agriculture, Forestry and Water Management, within the allocation of funds for special purposes for forests in 2015, Agreement no. 113-4/16, as of 4 February 2016, code 8301408.

\section{REFERENCES}

1. GOVERNMENT OF THE REPUBLIC OF SRPSKA 2015 Proposal of measures for redefining the organizational-economic and personnel position of the Public Enterprise "Forests of The Republic of Srpska". Government of the Republic of Srpska, Ministry of Agriculture, Forestry and Water Management, Banja Luka, Bosnia and Herzegovina, 48 p. URL: https://goo. gl/6TpyVN (25 April 2018)

2. VEZA I, CELAR S, PERONJA I 2015 Competences-based Comparison and Ranking of Industrial Enterprises using PROMETHEE Method. Procedia Engineer 100: 445- 449. DOI: https://doi.org/10.1016/i.proeng.2015.01.389

3. BALÁŽOVÁ E, LUPTÁKOVÁ J 2016 Application of the Economic Value Added index in the performance evaluation of forest enterprise. Journal of Forest Science 62 (5):191197. DOI: https://doi.org/10.17221/48/2015-JFS
4. DIAZ-BALTEIRO L, HERRUZO AC, MARTINEZ M, GONZALEZPACHON J 2006 An analysis of productive efficiency and innovation activity using DEA: An application to Spain's wood based industry. Forest Policy Econom 8 (7): 762-773. DOI: https://doi.org/10.1016/i.forpol.2005.06.004

5. GOLUBOVIĆ U 1971 Research of relative differential rents in the economic forests of Gorski Kotar. Sumar list 95 (1112): $364-418$

6. HAJDÚCHOVÁ I, GIERTLIOVÁ B, ŠULEK R 2017 Specifics of Forest Enterprises' Performance Measurement. Austrian J For Sci 1: 23-40

7. KRALJÍ B 1967 Working units in a forest-economic organization. Sumar list 91: 374-387

8. KRALJIĆ B 1975 Forest rent and constitutional provisions. Sumar list 99 (7-10): 244-253 
9. KRALIĆ B 1975 Simplified stimulating distribution in a forest-based organization based on the equalization of business conditions. Sumar list 99 (11-12): 421-430

10. KRALJIĆ B 1976 Separation of a part of the income, which depends on the extremely favorable natural, market and other conditions in the forestry. Sumar list 100 (10-12): 447-456

11. LEE JY 2005 Using DEA to measure efficiency in forest and paper companies. Forest Prod J 55 (1): 58-66

12. POTOČIĆ $Z 1961$ Nature and function of rent in the forest economy. Sumar list 85 (9-10): 348-356

13. RANKOVIĆ N 1996 Forest Economics. Faculty of Forestry, University of Belgrade, Belgrade, SR Yugoslavija, $361 \mathrm{p}$

14. ŠPORČIĆ M 2007 Evaluation of the performance of organizational units in forestry by non-parametric model. PhD Thesis, University of Zagreb, Faculty of Forestry, Croatia, $112 \mathrm{p}$

15. ŠPORČIĆ M, LANDEKIĆ M 2014 Nonparametric Model for Business Performance Evaluation in Forestry. In: Awrejcewic $\mathrm{J}$ (eds) Computational and Numerical Simulations. Intech Open, London, United Kingdom, 451-475. DOI: https://doi. org/10.5772/57042

16. ŠPORČIĆ M, MARTINIĆ I 2007 Assessment of the efficiency of work units in forestry by analyzing the data limitation. New Forestry Mechanisation 28 (1): 3-14

17. ŠPORČIĆ M, MARTINIĆ I, LANDEKIĆ M, LOVRIĆ M 2008 Analysis of data limitation as an efficiency method - possibility of application in forestry. New Forestry Mechanisation 29 (1): 51-59

18. ŠPORČIĆ M, MARTINIĆ I, LANDEKIĆ M, LOVRIĆ M 2009 Measuring Efficiency of Organizational Units in Forestry by Nonparametric Model. Croat J For Eng 30 (1): 1-13

19. WOLFSLEHNER B, VACIK H, LEXER MJ 2005 Application of the analytic network process in multi-criteria analysis of sustainable forest management. For Ecol Manag 207 (1-2): 157-170. DOI: https://doi.org/10.1016/i. foreco.2004.10.025

20. ČOMIĆ D, ŠKRBIĆ N, BEĆIROVIĆ DŽ, MILOVANOVIĆ M 2013 Survey of forestry organizations and institutions in the Republic of Srpska, Federation of B\&H, Republic of Serbia, Croatia and Montenegro. Bulletin of the Faculty of Forestry, University of Banja Luka 18: 57-90. URL: https://goo.gl/ UaH6tC (15 May 2018)

21. INSTITUTE OF PROFESSIONAL FINANCIAL MANAGERS (IPFM) 2009 Analysis of the Operation and Financial Condition of the Enterprise. Leonardo da Vinci programme project „Development and Approbation of Applied Courses Based on the Transfer of Teaching Innovations in Finance and Management for Further Education of Entrepreneurs and Specialists in Latvia, Lithuania and Bulgaria". IPFM, London, UK, 36-45. URL: https://goo.gl/if5JjY (2 October 2018)

22. BABIĆ Z, PLAZIBAT N 1998 Ranking of enterprises based on multicriterial analysis. Int J Prod Econ 56-57: 29-35. DOI: https://doi.org/10.1016/S0925-5273(97)00133-3

23. IVANIĆ M 2010 Principles of Economics. Faculty of Economy University of Banja Luka, Banja Luka, Bosnia and Herzegovina, $658 \mathrm{p}$

24. SHELDON GM 2003 The efficiency of public employment services: A nonparametric matching function analysis for Switzerland. J Prod Anal 20 (1): 49-70. DOI: https://doi. org/10.1023/A:1024870108435

25. VENNESLAND B 2005 Measuring rural economic development in Norway using data envelopment analysis. Forest Policy Econom 7 (1): 109-119. DOI: https://doi. org/10.1016/S1389-9341(03)00025-X
26. BAHOVEC V, NERALIĆ L 2001 Relative efficiency of agricultural production in county districts of Croatia. Mathematical Communications - Supplement 1 (1): 111119

27. SUBHASH CR 2004 Data Envelopment Analysis: Theory and Techniques for Economics and Operations Research. Press Syndicate of the University of Cambridge, Cambridge, United Kingdom, 1-14. URL: https://goo.gl/kmb8uT (18 September 2018)

28. SAATY TL 2001 Decision Making with Dependence and Feedback: the Analytic Network Process. RWS Publisher, Pittsburgh, USA, $360 p$

29. MENDOZA GA, SPROUSE W 1989 Forest planning and decision making under fuzzy environments. Forest Sci 35 (2): 481502. DOI: https://doi.org/10.1093/ forestscience/35.2.481

30. KANGAS J, KUUSIPALO J 1993 Integrating biodiversity into forest management planning and decision-making. For Ecol Manag 61 (1-2): 1-15. DOI: https://doi.org/10.1016/03781127(93)90186-Q

31. MENDOZA GA, MACOUN P, PRABHU R, SUKADRI D, PURNOMO H, HARTANTO H 1999 Guidelines for Applying Multi-Criteria Analysis to the Assessment of Criteria and Indicators. Center for International Forestry Research, Jakarta, Indonesia, 85 p. URL: https://goo.gl/7RJdKo (10 September 2018)

32. VACIK H, LEXER MJ 2001 Application of a spatial decision support system in managing the protection forests of Vienna for sustained yield of water resources. For Ecol Manag 143 (1-3): 65-76. DOI: https://doi.org/10.1016/ S0378-1127(00)00506-5

33. VACIK H, WOLFSLEHNER B, HECKL F, HACKL J 2001 Importance of impacts on forest ecosystems for a sustainable use and maintenance of biodiversity. In: Dellmann K (ed) Proceedings of the Sixth International Symposium on the Analytic Hierarchy Process, ISAHP 2001, Berne, Switzerland, 2-4 2001, pp 501-510

34. SCHMOLDT DL, KANGAS J, MENDOZA GA, PESONEN M (eds) 2001 The Analytic Hierarchy Process in Natural Resource and Environmental Decision Making. Kluwer, Dordrecht, The Netherlands, $307 \mathrm{p}$

35. ANANDA J, HERATH G 2003 The use of Analytic Hierarchy Process to incorporate stakeholder preferences into regional forest planning. Forest Policy Econ 5 (1): 13-26. DOI: https://doi.org/10.1016/S1389-9341(02)00043-6

36. PEARSE H 1992 Forestry Economics. The University of British Columbia press, Vancouver, Canada, $226 \mathrm{p}$

37. OESTEN G, ROEDER A 2012 Management von forstbetrieben - Band I. Institut für Forstökonomie der Universität Freiburg, Freiburg, Germany, $380 \mathrm{p}$

38. SPEIDEL G 1972 Planung im Forstbetrieb: Grundlagen und Methoden der Forsteinrichtung. Parey, Hamburg, Berlin, Germany, $267 \mathrm{p}$

39. KRALIĆ B 1968 Stimulating distribution of income to accounting units and personal incomes to billing places in a forest-based organization. Narodni šumar 5-6: 247-264

40. KRALIĆ B 1969 Financing of biological reproduction of cut wood. Sumar list 93 (3-4): 114-125

41. KRALJIĆ B 1969 Stimulating distribution of personal incomes to individual workers in a forest-based organization. Narodni šumar 8-9: 409-420

42. KRALIĆ B 1971 Principles of distribution in forestry. Methodological study of the Forest Research Institute of the Faculty of Forestry, University of Zagreb (II): 1-173

43. KRALIĆ B 1975 Stimulating internal distribution of income to work units in a forest-based organization. Sumar list 99 (11-12): 433-451 
44. DELIĆ S 2011 Basics of Forest Economics. Faculty of Forestry, University of Sarajevo, Sarajevo, Bosnia and Herzegovina, $245 p$

45. DELIĆ S, AVDIBEGOVIĆ M, BEĆIROVIĆ DŽ, MARIĆ B, MUTABDŽIJA S, BRAJIĆ A, PRUŽAN E 2011 Forest management costs in the Federation of $B \& H$ and cost management. Works of the Faculty of Forestry University of Sarajevo 1: 59-71

46. SABADI R 1992 Forest Economics. Školska knjiga, Zagreb, Croatia, $279 \mathrm{p}$

47. TODOROVIĆ Z, TODOROVIĆ I 2015 Methodology of scientific research in economics. Faculty of Forestry, University of Banja Luka, Banja Luka, Bosnia and Herzegovina, 241 p
48. KOCH R 1998 The 80/20 Principle - The secret of achieving more with the less. Nicolas Brealey Publishing, London, United Kingdom, 313 p. URL: https://goo.gl/37QgEW (24 March 2018)

49. HADŽIVUKOVIĆ S 1991 Statistical methods applied in agricultural and biological research. Faculty of Agriculture University of Novi Sad - Institute for Economics of Agriculture and Social Welfare (II), Novi Sad, Serbia, $572 \mathrm{p}$

50. KOPRIVICA M 2015 Forest statistics. Faculty of Forestry, University of Banja Luka, Banja Luka, Bosnia and Herzegovina, $381 p$

51. SHEVLYAKOV GL, OJA H 2016 Robust correlation: theory and applications - Wiley Series in Probability and Statistics. Wiley, Chichester, United Kingdom, $352 \mathrm{p}$ 